Research article

\title{
DISTRIBUTION OF ANTIBIOTIC RESISTANCE GENES IN ENTEROCOCCUS SPP. ISOLATED FROM MASTITIS BOVINE MILK
}

\author{
ERBAS Goksel*, PARIN Ugur, TURKYILMAZ Suheyla, UCAN Nese, OZTURK \\ Mehmet, KAYA Osman
}

Veterinary Faculty, Department of Microbiology, Isikli/AYDIN-TURKEY

(Received 05 January; Accepted 26 April 2016)

In this study, determination of enterococcus species that were isolated from mastitic milk samples, investigation of their susceptibilities to antibiotics and identification of the existence of resistance genes in resistant strains were conducted. The specimens consist of 600 mastitic milk samples that were collected from 242 cows. Isolation of enterococcus was carried out in selective media and 94 (15.6\%) Enterococcus spp. were isolated. A total of 94 species of Enterococci were identified using both sequencing and polymerase chain reaction (PCR). Enterococcus spp. isolates belong to 5 different species (E. faecalis, E. faecium, E. durans, E. hirae, E. mundtii) in sequence analysis and 4 different species (E. faecalis, E. faecium, E. durans, E. hirae) were identify by PCR method with specific primers. Analyzing 94 enterococcus strains by antibiotic sensitiveness test a high rate of resistance to tetracycline in $77(81.9 \%)$ isolates was shown. The tet resistance genes were identified as follows: 54 were tet $\mathrm{M}$ positive, 23 were tet $\mathrm{K}$ positive and 17 were positive on tet $\mathrm{M}$ and tet $\mathrm{K}$. Resistance to erythromycin was established in $27(28.7 \%)$ isolates $(25 \mathrm{ermB})$ while the chloramphenicol resistance gene was found in $10(10.7 \%)$ of isolates and the cat gene was identified in nine samples and one isolate was resistant to vancomycin $(1.06 \%)$ with the $\operatorname{VanA}$ gene confirmed. In conclusion, it was shown that E. faecalis has the biggest role in enterococcus originated mastitis and these strains were found to be mostly resistant to tetracycline. One vancomycine resistant isolate that had the $\operatorname{VanA}$ gene was also determined.

Key words: Antibiotic resistantance genes, Entrococcus, Mastitis, PCR, vanA

\section{INTRODUCTION}

Enterococci can cause many economically important animal diseases including bovine mastitis [1]. Mastitis reduces milk yield, increases health cost and makes milk less suitable for both consumption and processing [2]. Enterococcus can enter from the teat surface (if it is not disinfected properly) to the teat canal and might cause mastitis. Enterococci can be transmitted between the environment and the animal rather than

\footnotetext{
*Corresponding author: e-mail: gerbas@adu.edu.tr
} 
from animal to animal [3]. When data were analyzed, the incidence of Enterococcus spp.as aetiological agents of bovine mastitis varied from 0 [4] to $46 \%$ [5,6].

In addition to their importance in disease, enterococci can generate antibiotic resistance against a number of antibiotics. This resistance evolves in the bacteria that have resistance genes. Enterococci may harbor multi-drug resistance for antimicrobial agents such as cephalosporins and aminoglycosides and the van gene can be transfered to other gram positive bacteria. Vancomycin-resistant enterococci (VRE) were first reported in 1998 and their incidence has increased rapidly through the world after that [7]. VRE strains have been mentioned in human sciences and subsequently in veterinary sciences in previous studies, but the gene has not been discovered in our province until now.

In addition to their present resistance to antibiotics at, bacteria can generate antibiotic resistance with remarkably new mechanisms and can transfer this resistance to each other $[8,9]$. Resistance genes are often easily transferred to other species through conjugative transposons and plasmids showing the broad host profile [10].

In this study, determination of enterococcus species that were isolated from mastitic milk samples, investigation of their susceptibilities to antibiotics and identification of the resistance genes was conducted.

\section{MATERIALS AND METHODS}

\section{Sample Collection}

In this study, 600 mastitic milk samples that were collected from 242 cows in 38 different private dairy cattle farms in Aydin were included in the study. Clinical mastitis was diagnosed according to the presented changes in the udder and milk by veterinary practitioners. Changes in the udder included pain, swelling, warmth and abnormal appearance of milk (blood tinged milk, watery secretions, clots, pus). Cows that did not have clinical mastitis were subjected to further investigation for subclinical mastitis using California Mastitis Test (CMT). The procedures and interpretations have been described previously [11]. For collection of milk samples, the teat tips were cleaned using $70 \%$ alcohol moistened swabs and allowed to dry. After discarding the first few milk jets, $2-5 \mathrm{ml}$ of the milk samples were collected into sterile $5 \mathrm{ml}$ glass flasks. Approximately 6-8 mastitic cattle were sampled and tested for the presence of enterococci, on each of 38 dairy farms from end of 2012 to 2014.

\section{Isolation and Identification of Enterecocci}

For isolation, one full loop of mastitic milk sample was inoculated to selective Chromocult ${ }^{\circledR}$ Enterococci Broth (Merc, Darmstadt, Germany). The enrichment broth was incubated for $18-24 \mathrm{~h}$ at $37^{\circ} \mathrm{C}$. Colour change was evaluated as an indicator of enterococci growth in the medium. Positive cultures were transferred to $\mathrm{BBL}^{\mathrm{TM}}$ Enterococcosel Agar (EA) (Becton Dickinson, Heidelberg, Germany) for the isolation 
of enterococci. Plates were incubated overnight at $37^{\circ} \mathrm{C}$. At the end of the period black and dark brown colonies were subcultured onto Difco mEnterococcus (Difco, Heidelberg, Germany) agar plates and incubated at $37^{\circ} \mathrm{C}$ for 48 h. [12]. For the separation at the level of the genus Enterococcus, the presumptive positive colonies Gram stain, catalase tests on slide was performed as well as growth ability in nutrient broth (Merc, Darmstadt, Germany) containing 6.5\% NaCl were made [13]. The purified and confirmed (salt tolerant and catalase-negative) enterococci were inoculated into Enterococcosel Agar (Becton Dickinson, Heidelberg, Germany) plates and incubated overnight at $37^{\circ} \mathrm{C}$. All suspicious colonies were stored in Brain Heart Infusion Broth (Oxoid, Hampshire, UK) with $20 \%$ glycerin at $-20^{\circ} \mathrm{C}$ until identified using molecular methods.

\section{Antimicrobial Susceptibility Testing}

The antimicrobial sensitivity phenotypes of bacterial isolates were determined using a Kirby-Bauer disk diffusion assay according to the standards and interpretive criteria described by Clinical and Laboratory Standards Institute [14]. The following antibiotics were used: ampicillin (AMP), $10 \mu \mathrm{g}$; tetracycline (TET), $30 \mu \mathrm{g}$; streptomycin (STR), $10 \mu \mathrm{g}$; vancomycin (VA), $30 \mu \mathrm{g}$; Teicoplanin (TEC), $30 \mu \mathrm{g}$; erythromycin (E), $15 \mu \mathrm{g}$; ciprofloxacin (CIP), $5 \mu \mathrm{g}$; chloramphenicol (C), $30 \mu \mathrm{g}$; gentamicin $(\mathrm{CN}), 120 \mu \mathrm{g}$; The disks were purchased from Oxoid (Hemakim, Izmir, Turkey) and the results were recorded based on CLSI guidelines [14]. The reference strains Enterococcus faecalis ATCC 29212 and Staphylococcus aureus ATCC 29213 were used as the quality control.

\section{Molecular Methods}

The enterococus suspicious colonies were confirmed genetically using genus [15] and species [16] specific primers for the PCR. The Uniplex PCR was used for the detection of antibiotic resistance genes in resistance strains. All Oligonucleotide primers used to in the study are listed in Table 1.

\section{DNA extraction}

Genomic DNA was isolated by the commercial extraction kit (InstaGene Matrix, Germany). The integrity of DNA isolated by electrophoresis was shown to be complete [17]. Quantitative determinations of the isolated DNAs were performed by nano spectrophotometer (Thermo NanoDrop 2000/2000c). DNA quantity was measured with regard to absorbance value, in conclusion A260 / A280 ratios between 1.8 and 2 DNAs were considered useful [18].

\section{Polimerase Chain Reaction (PCR)}

All the PCR reactions were carried out in a final volume of $30 \mu$ containing 1 X PCR buffer, $2 \mathrm{mM} \mathrm{MgCl}, 200 \mathrm{mM}$ each of the four dNTPs, $0.5 \mathrm{mM}$ of each primer and 
1.25 units of Taq DNA polymerase. The cycles used were $95^{\circ} \mathrm{C}$ for $5 \mathrm{~min}, 95^{\circ} \mathrm{C}$ for $30 \mathrm{~s}, 51^{\circ} \mathrm{C}\left(d d l \mathrm{E}_{\text {faccium }}\right), 53^{\circ} \mathrm{C}\left(d d l_{\text {E.faecalis. }}\right) 55^{\circ} \mathrm{C}\left(d d l_{\text {Effacalis }}\right) 57^{\circ} \mathrm{C}\left(d d l_{\text {birae }}\right.$ and $\left.d d l_{\text {durann }}\right), 48^{\circ} \mathrm{C}$ for $($ tet $\mathrm{K}, \operatorname{cat}, \operatorname{erm} \mathrm{B}), 51^{\circ} \mathrm{C}$ (for tet $\mathrm{M}$ ) and $56^{\circ} \mathrm{C}$ (for van $\left.\mathrm{A}\right) 30 \mathrm{~s}$ and $72^{\circ} \mathrm{C}$ for $60 \mathrm{~s}$ for the next 35 cycles, $72^{\circ} \mathrm{C}$ for $15 \mathrm{~min}$ were used fort the last cycle. The amplification products were analysed by electrophoresis on $1.5 \%$ agarose gel at $100 \mathrm{~V}$ for $30 \mathrm{~min}$ in Tris-acetate-EDTA buffer and revealed in ethidium bromide $(20 \mu \mathrm{g} / \mathrm{ml})$. Amplicons, which were taken from bacterias, sequenced to identification.

Table 1. Oligonucleotide primers used to in the study

\begin{tabular}{|c|c|c|c|c|}
\hline & Primer & Sequence (5'-3') & $\begin{array}{l}\text { Amplicon sizes } \\
\text { (bp) }\end{array}$ & Reference \\
\hline 1 & $\begin{array}{l}\text { Ent1 } \\
\text { Ent2 }\end{array}$ & $\begin{array}{l}\text { TACTGACAAACCATTCATGATG } \\
\text { AACTTCGTCACCAACGCGAAC }\end{array}$ & 112 & [15] \\
\hline 2 & $\begin{array}{l}\text { DDF } \\
\text { DDR }\end{array}$ & $\begin{array}{l}\text { CACCTGAAGAAACAGGC } \\
\text { ATGGCTACTTCAATTTCACG }\end{array}$ & 475 & \multirow{2}{*}{ [16] } \\
\hline 3 & $\begin{array}{l}\text { FAC11 } \\
\text { FAC21 }\end{array}$ & $\begin{array}{l}\text { GAGTAAATCACTGAACGA } \\
\text { CGCTGATGGTATCGATTCAT }\end{array}$ & 1.091 & \\
\hline 4 & $\begin{array}{l}\text { DU1 } \\
\text { DU2 }\end{array}$ & $\begin{array}{l}\text { CCTACTGATATTAAGACAGC } \\
\text { TAATCCTAAGATAGGTGTTTG }\end{array}$ & 295 & \multirow{2}{*}{ [12] } \\
\hline 5 & $\begin{array}{l}\text { HI1 } \\
\text { HI2 }\end{array}$ & $\begin{array}{l}\text { CTTTCTGATATGGATGCTGTC } \\
\text { TAAATTCTTCCTTAAATGTTG }\end{array}$ & 187 & \\
\hline 6 & $\operatorname{van} \mathrm{A}$ & $\begin{array}{l}\text { GGG AAA ACG ACA ATT GC } \\
\text { GTA CAA TGC GGC CGT TA }\end{array}$ & 732 & [17] \\
\hline 7 & tet $\mathrm{M}$ & $\begin{array}{l}\text { GTGGACAAAGGTACAACGAG } \\
\text { CGGTAAAGTTCGTCACACAC }\end{array}$ & 406 & {$[18]$} \\
\hline 8 & tet $\mathrm{K}$ & $\begin{array}{l}\text { CAATACCTACGATATCTA } \\
\text { TTGAGCTGTCTTGGTTCA }\end{array}$ & 352 & [19] \\
\hline 9 & erm $\mathrm{B}$ & $\begin{array}{l}\text { GAAAAGTACTCAACCAAATA } \\
\text { AGTAACGGTACTTAAATTGTTTAC }\end{array}$ & 639 & [20] \\
\hline 10 & $\begin{array}{l}\operatorname{cat} \mathrm{TCF} \\
\operatorname{cat} \mathrm{TCR}\end{array}$ & $\begin{array}{l}\text { CATATCAAATGAACT"TTAATA } \\
\text { CGTTTTGTGAAGTAGTACACT }\end{array}$ & 718 & [21] \\
\hline
\end{tabular}

\section{Sequence}

The amplicons with the expected size were sent to Macrogen Korea in 96 well plates for sequence analysis (Macrogen Inc., Seoul, Korea). Sequence analysis was done after purification using ABI Primse sequencing system by Macrogen Inc. The obtained sequences were compared to the gene bank using Nucleotide-Nucleotide BLAST software at National Centre of Biotechnology Information web page (http://www. ncbi.nlm.nih.gov).

\section{RESULTS}

\section{Isolation and Identification}

In this study, 94 (15.6\%) Enterococcus spp. were isolated from 600 mastitis milk samples that were collected from 242 cows. Isolation of enterococcus was carried out in 
selective media. 1371 bp length of amplicons were obtained by 16S PCR to control genus specific PCR with sequence analysis and existence of bacterial DNA in samples.

Thus, it was determined that DNA was extracted in all 94 isolated samples. All the microorganisms grown in EA are Enterococcus spp. were also confirmed by sequence analysis. PCR was carried out by specific primers to determine enterococcus isolates at the genus level accurately. The isolated and identified 94 isolates were specified as Enterococcus spp. by using genus and species level PCR (Figure 1). 56 of them were identified as E. faecalis while 20 of them were E. faecium, 11 of them were E. hirae and 7 of them were E. durans (Figure 2)

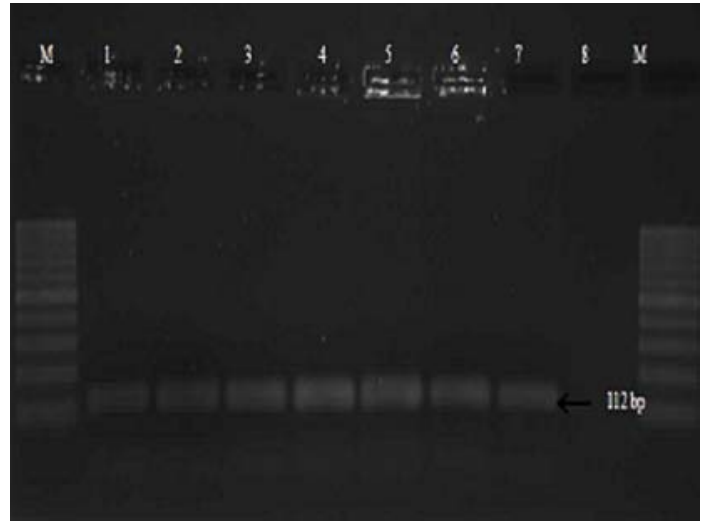

Figure 1. Enterococcus spp. PCR electrophoresis image 1-6: Enterococcus spp. field isolates 7: Positive control (E. faecalis ATCC 29212) 8: negative control (E. coli ATCC 25922) M: 100 bp DNA ladder (Vivantis, Selangor Darul Ehsan, Malaysia)

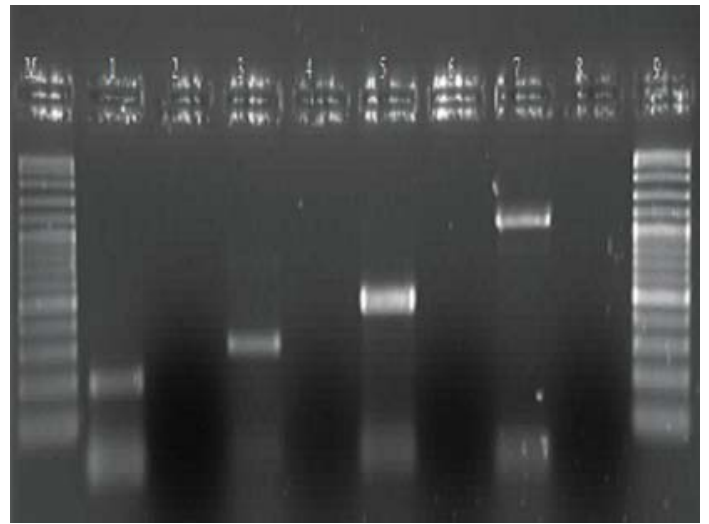

Figure 2. Enterococcus species specific PCR electrophoresis image.

1. E. hirea (188 bp) 2. E. hirae PCR negative control 3. E. durans (295 bp) 4. E. durans negative control 5. E. faecalis PCR (475 bp) 6. E. faecalis PCR negative control 7. E. faecium (1091 bp) 8. E. faecium negative control 


\section{Antibiotic Susceptibility}

In total, from the identified 94 enterococci, $77(81.9 \%)$ tetracycline, $27(28.7 \%)$ erythromycin, $10(10.7 \%)$ chloramphenicol and $1(1.06 \%)$ vancomycin-resistant strains were determined according to Kirby-Bauer disk diffusion test (Table 2).

\section{Antibiotic Resistant Genes}

Results of the examination of the antibiotic resistance genes showed that, 54 of tetracycline resistant isolates carry tet $\mathrm{M}$ gene, 23 of them carry tet $\mathrm{K}, 17$ of them carry both tet $\mathrm{M}$ and tet $\mathrm{K}$ genes. It was also determined that 25 of 27 erythromycin resistant isolates carry erm $\mathrm{B}$ gene while 9 of 10 chloramphenicol resistant isolates carry cat gene and 1 vancomycin resistant isolate carry vanA gene (Table 2) (Figure 3).

Table 2. Antibiotic resistance ratios and distribution of resistant genes

\begin{tabular}{lcl}
\hline Antibiotic & Resistance Ratio (n:94) & Distribution of resistant genes \\
\hline \multirow{2}{*}{ Tetracycline } & $77(81.9 \%)$ & 54 tetM \\
& & 23 tetK \\
Erythromycin & $27(28.7)$ & 17 tetM and tetK \\
Chloramphenicol & $10(10.7)$ & $25 \mathrm{ermB}$ \\
\hline Vancomycin & $1(1.06)$ & $9 \mathrm{cat}$ \\
\hline
\end{tabular}

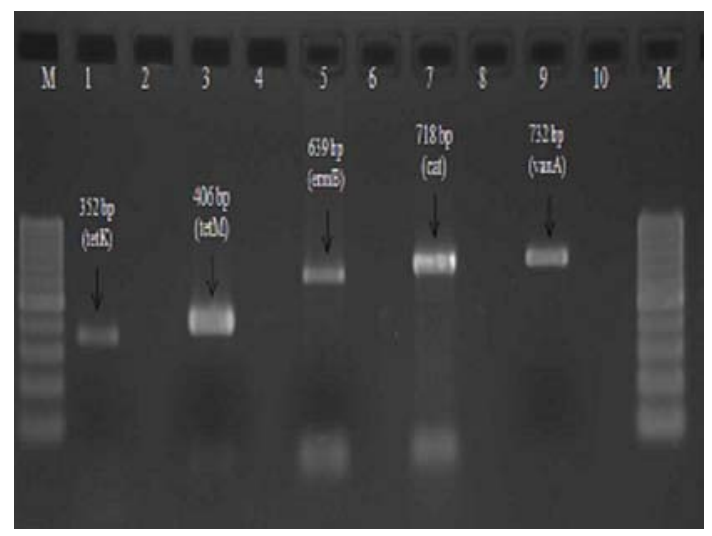

Figure 3. PCR electrophoresis image of antibiotic resistance genes.

1. tet $\mathrm{K}$ (352 bp) 2. tet $\mathrm{K}$ negative control 3. te $\mathrm{M}$ (406 bp) 4. tet $\mathrm{M}$ negative control 5. erm $\mathrm{B}$ (639 bp) 6. ermB PCR negative control 7. cat PCR (718 bp) 8. cat negative control 9. vanA PCR (732 bp) 10. vanA negative control

\section{DISCUSSION}

Enterococcus species are bacterial agents that exist as a natural flora in the intestinal tract of human and animals and they can cause mastitis in cows. It has been known 
that enterococcus is resistant to many antibiotics and that resistant traits could be easily transferred to other bacteria. In this study, species of isolates and resistance genes in antibiotic resistant strains were determined by PCR using specific primers.

As a result, $94(15.6 \%)$ of the Enterococcus spp. were isolated and identified from analyzed 600 mastitic milk samples. E. faecalis was the dominant species among the isolates and it was found in $59.6 \%$ of samples. The E. faecium was detected in $21.3 \%$ of the samples. Obtained results are similar to other studies on the prevalence of Enterococcus in milk from cows with mastitis [19-22].

Enterococcus species were encountered in many mastitic milk studies in Turkey at different rates, such as $4.22 \%$ by Macun et al. [23], 3.73\% by Yesilmen et al. [24] and $10.9 \%$ by Kuyucuoglu [25], however, Enterococcus were isolated at a higher rate $(15.6 \%)$ in this work. The differences between laboratories could be related to specific selective media used for Enterococcus isolation from mastitic milk samples.

Enterococci were determined to have resistance to many antibiotics such as tetracycline, erythromycin, cephalosporin, aminoglycoside and clindamycin in clinic applications [26] More than one gene were found responsible for vancomycin resistance in Enterococi. VanA resistant strains were also highly resistant to vancomycin and teicoplanine [27].

From 94 Enterococcus strains isolated in this work, 77 of them $(81.9 \%)$ were resistant to tetracycline, 27 of them $(28.7 \%)$ were resistant to erythromycin, 10 of them $(10.7 \%)$ were resistant to chloramphenicol and 1 isolate was resistant to vancomycin $(1.06 \%)$.

Genetic characterization of resistance genes from these strains, has shown that 54 carry tet $\mathrm{M}$ gene while 23 of them were tet $\mathrm{K}$ positive and 17 of them have both tet $\mathrm{M}$ and tet $\mathrm{K}$. It was also determined that 25 of 27 erythromycin resistant isolates carry the ermb gene while 9 of 10 chloramphenicol resistant isolates carry the cat gene and 1 vancomycin resistant isolate carries the vanA gene. Vancomycin resistant E. faecalis isolate were also detected to have resistance to tetracycline and erythromycin by carrying tet $\mathrm{M}$ and ermb genes.

In a study carried out by Nam et al. [22], all of the 105 Enterococcus isolates were found susceptible to ampicillin, gentamycin and vancomycin, but resistance to tetracycline was described at a rate of $69.5 \%$. Multiple drug resistance was observed in $30.4 \%$ of all strains with penicillin, tetracycline and erythromycin.

In another study [25], 43 Enterococci were isolated from 392 CMT (California Mastitis Test) positive samples and these strains were identified as E. faecalis (53.4\%) and E. faecium (18.6\%). E. faecalis strains were found resistant to tetracycline, erythromycin, penicillin and vancomycin, at a rate of $91.3 \%, 82.6 \%, 78.2 \%$ and $4.3 \%$, respectively. Results from research work from other authors implicate that the resistance to tetracycline antibiotics is based on the intensive use of these antibiotics in field conditions.

Findings about resistance to important antibiotics from isolated enterococci in our study were mostly found compatible with previously published results [22,23,25]. Resistance 
rates of tested antibiotics were low except for tetracycline and the encountered genes were resistance genes that normally exist in enterococci.

van $\mathrm{A}$ and $\operatorname{van} \mathrm{B}$ type resistances were found to be the most common resistances in $E$. faecium strains that were isolated from humans in Europe [28]. E. faecium is a common isolate and it carries vanA gene as it was determined by Unal et al. [29] when they analyzed in the isolated VRE originating from patients in our country. Reinert et al. [30] identified $1.5 \%$ vancomycin resistance in 730 enterococcus strains isolated from various materials. Aarestrup et al. [31] compared the antibiotic resistant genes and their phenotypes in humans, broilers and pigs and results were found quite similar. Vancomycin resistant enterococcus were isolated from turkey's feces, worker's stool, turkey's slaughterhouse and the people in the residential area close to the slaughterhouse at the turkey farm, by a rate of $50 \%, 39 \%, 20 \%$ and $14 \%$, respectively [32]. Three of 16 enterococcus strains isolated from mastitic milk samples were identified vancomycin resistant [5]. Two of these 3 strains were E. gallinarum and the other one was E. faecalis, as in our study. According to the data published by EFSA [33], vancomycin resistance in E. faecalis was just determined in The Netherlands (at a rate of 1\%), as well as in all the research studies conducted in European Countries.

Seputiene et al. [34] investigated the antibiotic resistant genes and virulence factors in E. faecalis and E. faecium strains isolated from sick farm animals (pigs, poultry and cattle). $83 \%$ of all erythromycin resistant E. faecium and all E. faecalis were observed to have erm $\mathrm{A}$ and $\mathrm{erm} \mathrm{B}$ genes. Tetracycline resistant $47 \%$ of E. faecalis and $19 \%$ of E. faecium were found to carry only tetM, while E. faecalis (8\%) and E. faecium $(23 \%)$ had only tet $\mathrm{L}$. Both tet $\mathrm{M}$ and tet $\mathrm{L}$ gene combination was at a rate of $42 \%$ for E. faecalis and $52 \%$ for E. faecium. Vancomycin resistant enterococcus was not identified in this study. Results of this study showed parallelism with our study in terms of finding tet $\mathrm{M}$ in tetracycline resistant E. faecalis. It was concluded tet $\mathrm{M}$ gene has a more dominant character.

According to our study, isolates of E. faecalis were identified resistant to tetracycline and erythromycin and carry vanA gene. From this point of view van A gene has great importance for having the ability to transfer this resistance to Gram (-) and Gram (+) bacteria.

In conclusion, E. faecalis has a huge part in enterococcus originated mastitis and these strains show resistance to tetracycline and erythromycin. Determining antibiotic resistance genes in enterococcus isolates signify that there is a possibility of genetic transfer of resistant genes to other pathogenic and commensal bacteria. Importantly we detected vancomycin resistance in one isolate. The van $\mathrm{A}$ gene was detected in this particulate isolate. It is thought that enterococcus species that carry the vanA gene can transfer the resistance gene to animals and/or humans thus creating a potential risks for human health.

\section{Acknowledgements}

This Research project has been approved by the Animal Research Ethics Committee of University of Adnan Menderes (2012-068), and supported by the Adnan Menderes University Scientific Research Projects Unit (ADU-BAP Project code: VTF-13006). 


\section{Authors' contributions}

EG and PU carried out the molecular studies. UN and EM did sample collections and laboratory studies. TS and KO participated in the design and coordination and helped to draft the manuscript. All authors read and approved the final manuscript.

\section{Declaration of conflicting interests}

The author(s) declared no potential conflicts of interest with respect to the research, authorship, and/or publication of this article.

\section{REFERENCES}

1. Devriese LA, Laurier L, De Herdt P, Haesebrouck F: Enterococcal and streptococcal species isolated from faeces of calves, young cattle and dairy cows. J Appl Bacteriol 1992, 72:29-31.

2. Cengiz S, Dinc G, Sogut MÜ: Detection of several virulence properties, antibiotic resistance and phylogenetic relationship in E. coli isolates originated from cow mastitis. Acta Vet Beograd 2014, 64 (4):413-425

3. Rossitto PV, Ruiz L, Kikuchi Y, Glenn K, Luiz K, Watts JL, Cullor JS: Antibiotic susceptibility patterns for environmental streptococci isolated from bovine mastitis in central California dairies. J Dairy Sci 2002, 85:132-138.

4. Osteras O, Solverod L, Reksen O: Milk culture results in a large Norwegian survey - effects of season, parity, days in milk, resistance, and clustering. J Dairy Sci 2006, 89: 1010-1023.

5. Kateete DP, Kabugo U, Baluku H, Nyakarahuka L, Kyobe S, Okee M, Najjuka CF, Joloba ML: Prevalence and Antimicrobial Susceptibility Patterns of Bacteria from Milkmen and Cows with Clinical Mastitis in and around Kampala, Uganda. Plos One. [www.plosone.org] 2013, May V:8 Issue 5, e63413.

6. Gurler H, Findik A, Gultekin N, Ay SS, Ciftci A, Koldas E, Arslan S, Findik M: Investigation on the Etiology of Subclinical Mastitis in Jersey and Hybrid Jersey Dairy Cows. Acta Vet Beograd 2015, 65 (3):358-370

7. Kang HM, Jung BY, Moon JS, Kang MS, Kim JM, Chung I: Distribution of Vancomycinresistant (VRE) and Van Gene Types in Domestic Animals. [http://210.101.116.28/W_ files/kiss3/0b700851_pv.pdf], 12 Feb 2015.

8. Murray BE: The life and times of the Enterococcus. Clin Microbiol Rev 1990, 3:46-65.

9. Klare I, Werner G, Witte W: Enterococci. Habitats, infections, virulence factors, resistances to antibiotics, transfer of resistance determinants. Contrib Microbiol 2001, 8, 108-122.

10. Coleri A, Cokmus C: Molecular Mechanisms of Resistance to Glycopeptide Antibiotics in Enterococcus Species and Modes of Gene Transfer Turk Hij Den Biyol Derg 2008, 65 (2):87-96.

11. Quinn PJ, Carter ME, Markey B, Carter GR: Clinical Veterinary Microbiology. Mosby-Year Book Europe Limited, Lynton House, London, England; 1994, 40-190. 
12. Jackson CR, Fedorka-Cray PJ, Barrett JB: Use of a genus- and species-specific multiplex PCR for identification of enterococci. J Clin Microbiol 2004, 42:(8):3558-3565.

13. Lanthier M, Scott A, Lapen D, Zhang Y, Topp E: Frequency of virulence genes and antibiotic resistances in Enterococcus spp. isolates from wastewater and feces of domesticated mammals and birds, and wildlife. Can J Microbiol 2010, 56:715-729.

14. CLSI: Performance standards for antimicrobial susceptibility testing. Twenty-First Informational Supplement. Clinical and Laboratory Standards Institute 2011, M02-A10 and M07-A08 vol. 31Wayne, PA.

15. Ke D, Picard FJ, Martineau F, Ménard C, Roy PH, Ouellette M, Bergeron MG: Development of a PCR assay for rapid detection of enterococci. J Clin Microbiol 1999, 37: 3497-503.

16. Vilela MA, de Souza SL, Palazzo ICV, Ferreira JC, de Morais Jr. MA, da Costa Darini AL, de Morais MMC: Identification and molecular characterization of Van A-type vancomycin-resistant Enterococcus faecalis in Northeast of Brazil. Mem Inst Oswaldo Cruz 2006, 101(7):715-719.

17. Sambrook J, Fritsch EF, Maniatis T: Molecular cloning: A laboratory manual. $2^{\text {nd }}$ edt. Cold Spring Harbor, New York: Cold Spring Harbor Press; 1989, 2.60-2.80.

18. Turner PC, Mclennan AG, Bates AD, White MRH: Instant Notes in Molecular Biology. Biologia Plantarumn1999, 42(3):462-462.

19. Watts JL: Characterization and identification of Streptococci isolated from bovine mammary glands. J Dairy Sci 1988, 71:1616-1624.

20. Jayarao BM, Dore JJE, Oliver SP: Restrictionfragment length polymorphism analysis of $16 \mathrm{~S}$ ribosomal DNA Streptococcus and Enterococcus species of bovine origin. J Clin Microbiol 1992, 30:2235- 2240.

21. Devriese LA, Vancanneyt M, Descheemaeker P, Baele M, van Landuyt HW, Gordts B, Butaye P, Swings J, Haesebrouck F: Differentiation and identification of Enterococcus durans, E. hirae, and E. vitillorum. J Appl Microbiol 2002, 92:821-7.

22. Nam HM, Lim SK, Moon JS, Kang HM, Kim JM, Jang KC, Kim JM, Kang MI, Joo YS, Jung SC: Antimicrobial resistance of enterococci isolated from mastitic bovine milk samples in Korea. Zoonoses Public Health 2010, 57(7-8):e59-64.

23. Macun HC, Yagci IP, Unal N, Kalender H, Sakarya F, Yildirim M: Agent Isolation and Antibiotic Resistance in Dairy Cows with Subclinical Mastitis in Kirlkkale. J Fac Vet Med Univ Erciyes 2011, 8(2):83-89.

24. Yesilmen S, Ozyurtlu N, Bademkiran S: The Isolation of Subclinical Mastitis Agents and Determination of the Sensitive Antibiotics in Dairy Cows in Diyarbakır Province. Dicle Üniv Vet Fak Derg 2012, 1(4):24-29.

25. Kuyucuoglu Y: Antibiotic resistances of enterococci isolated from bovine subclinical mastitis. Eurasian J Vet Sci 2011, 27(4):231- 234.

26. Urbaskova P: Antibiotic Resistance Bacteria (Rezistence bakterií k antibiotikům). Vybrané metody. 1998, ISBN 80-238-3106-2. Trios Praha.

27. Cetinkaya Y, Falk P, Mayhall CG: Vancomycin-Resistant Enterococci. Clinical Microbiology Reviews 2000, 686-707.

28. Werner G, Coque TM, Hammerum AM, Hope R, Hryniewicz W, Johnson A, Klare I, Kristinsson KG, Leclercq R, Lester $\mathrm{CH}$ : Emergence and spread of vancomycin-resistance among enterococi in Europe. Eurosurveillance 2008, 13:1-11.

29. Unal N, Dilik Z, Yildirim M: Isolation of a vanA Positive Enterococcus faecium from Commercial Broiler Farms in Turkey. Kafkas Univ Vet Fak Derg 2010, 16 (1): 127-129. 
30. Reinert RR, Conrads G, Schlaeger JJ, Werner G, Witte W, Luetticken R, Klare I: Survey of antibiotic resistance among enterococci in North Rhine-Westphalia, Germany. J Clin Microbiol 1999, 37:1638-1641.

31. Aarestrup FM, Bager F, Andersen JS: Association between the use of avilamycin for growth promotion and the occurrence of resistance among Enterococcus faecium from broilers epidemiological study and changes over time. Microb Drug Resist 2000, 6:71-75.

32. van den Bogaard AE, Mertens P, London NH, Stobberingh EE: High prevalence of colonization with vancomycin- and pristinamycin-resistant enterococci in healthy humans and pigs in the Netherlands: is the addition of antibiotics to animal feeds to blame? J Antimicrob Chemother 1997, 40:454-456.

33. EFSA: EU Summary Report on antimicrobial resistance in zoonotic and indicator bacteria from humans, animals and food in 2013. EFSA Journal 2015, 13(2):4036.

34. Seputiene V, Bogdaite A, Ruzauskas M, Suziedeliene E: Antibiotic resistance genes and virulence factors in Enterococcus faecium and Enterococcus faecalis from diseased farm animals: pigs, cattle and poultry Pol J Vet Sci 2012, 15(3); 431-438.

\title{
DISTRIBUCIJA GENA REZISTENCIJE NA ANTIBIOTIKE KOD ENTEROCOCCUS SPP. IZOLOVANIH IZ UZORAKA MLEKA KRAVA SA MASTITISOM
}

\author{
ERBAS Goksel, PARIN Ugur, TURKYILMAZ Suheyla, UCAN Nese, OZTURK \\ Mehmet, KAYA Osman
}

U ovoj studiji izvršeno je određivanje Enterococcus spp u uzorcima mleka krava sa mastitisom, kao i odredivanje njihove osetljivosti na antibiotike i identifikacija gena rezistencije kod izolovanih rezistentnih sojeva. Uzeto je 600 uzoraka mleka od 242 krave sa mastitisom. Izolacija enterokoka je izvršena na selektivnim podlogama, pri čemu je izolovano 94 (16,6\%) Enterococcus spp. Primenom sekvencioniranja i PCR-om ukupno je izolovano 94 Enterococcus spp. Sveukupno 5 vrsta (E. faecalis, E. faecium, E. durans, E. hirae, E. mundtii) je izolovano sekvencioniranjem, a 4 (E. faecalis, E. faecium, E. durans, E. hirae) je identifikovano pomoću specifičnih prajmera metodom PCR. Ispitivanjem antibiotske rezistencije 94 sojeva izolovanih enterokoka visoka stopa rezistencije na tetracikline je određena u 77 izolata $(81,9 \%)$. Tet gen je utvrden sa sledećom stopom: 54 tetM pozitivno, 23 tetK pozitivno i 17 tetM i tetK pozitivno. Rezistencija na eritromicin je ustanovljena kod 27 (28,7\%) izolata (25 ermB), dok je gen rezistencije na hloramfenikol zabeležen u $10(10,7)$ izolata. Cat gen je identifikovan kod 9 uzoraka, a jedan izolat je bio rezistentan na vankomicin $(1,06 \%)$ uz potvrdu VanA gena.

Možemo zaključiti da E. faecalis ima ključnu ulogu u nastanku enterokoknog mastitisa pri čemu su izolovani sojevi bili rezistentni na tetraciklin. Jedan vankomicin rezistentan izolat je istovremeno imao izolovan VanA gen. 